\title{
Thermodynamics of Peptide and Non-Peptide Interactions with the Human 5HT1a Receptor
}

\author{
Brian Hall Andrea Burnett Alicia Christians Cortney Halley Eric Goldstein \\ Harish V. Thiagaraj Keith K. Parker \\ Department of Biomedical and Pharmaceutical Sciences, and Center for Structural and Functional Neuroscience, \\ Skaggs School of Pharmacy, University of Montana, Missoula, Mont., USA
}

\section{Key Words}

Serotonin $\cdot 5 \mathrm{HT} 1$ a receptor $\cdot$ Intracellular loop peptides •

Dipropyltryptamine $\cdot$ Enthalpy $\cdot$ Entropy

\begin{abstract}
The human serotonin 1a receptor ( $\mathrm{H} 5 \mathrm{HT} 1 \mathrm{aR})$ is a highly studied member of the 7 transmembrane $G$ protein-coupled receptors. This model receptor, negatively coupled to adenylyl cyclase via Gi, is linked to physiological processes such as cognition and mood regulation and to associated disorders like anxiety and depression. Gibb's free energies, enthalpies, and entropies were calculated for the agonist $\left[{ }^{3} \mathrm{H}\right] 8-\mathrm{OH}-$ DPAT in the presence of synthetic peptides derived from sequences of intracellular loops 2 and 3 of the H5HT1aR. For comparative purposes, the thermodynamic parameters were also determined in the presence of a limited number of ligand-binding site substances (the partial agonist dipropyltryptamine [DPT], and the full agonist $\left[{ }^{3} \mathrm{H}\right] 8-\mathrm{OH}-\mathrm{DPAT}$ alone). All of these thermodynamic measurements were based on binding data accumulated over a range of temperatures ( 0 $35^{\circ} \mathrm{C}$ ). Representative examples of binding constant experiments and van't Hoff plots are shown to establish the thermodynamic variables. Although differences exist between
\end{abstract}

the peptides themselves and the non-peptide agonists, in all situations the binding events are highly entropy driven. Differences between this information and published data for rat 5HT1aR are discussed, as are relationships to other receptor systems. Overall, the conclusions should be useful in further defining a comprehensive model of $5 \mathrm{HT} 1 \mathrm{aR}$, and for future development of binding-site and non-binding-site directed agents for the receptor.

Copyright $\odot 2010$ S. Karger AG, Basel

\section{Introduction}

Regulation of serotonin receptors (5HTRs) by $5 \mathrm{HT}$ and related drugs is significant as $5 \mathrm{HT}$ is associated with a number of physiological and pathological processes $[1$, 2]. The highly studied $5 \mathrm{HT} 1 \mathrm{aR}$ is especially linked to the following biological and psychological events: mood regulation, cognition, depression, anxiety, obsessive-compulsive disorders, panic disorders, schizophrenia, headache, thermoregulation, and cardiovascular/renal processes [3-5]. There are indications in the literature that H5HT1aR-linked changes in thermoregulation may be predictive of antidepressant clinical drug response [6].

\section{KARGER}

(c) 2010 S. Karger AG, Basel

Fax +41613061234 E-Mail karger@karger.ch www.karger.com www.karger.com/pha
Keith K. Parker

Department of Biomedical and Pharmaceutical Sciences (MPH I02)

Skaggs School of Pharmacy, University of Montana, 32 Campus Drive No. 1552 Missoula, MT 59812-1552 (USA)

Tel. +1 406243 4235, Fax +1 406243 5228, E-Mail keith.parker@umontana.edu 
Interestingly, the receptor has recently been associated with antioxidant processes [7], and there is a developing literature associating $\mathrm{H} 5 \mathrm{HT} 1 \mathrm{aR}$ with addictive processes [8].

The H5HT1aR is a prototypical member of a very large class of signal-transducing receptors, the 7 transmembrane domains (7TMD), GTP-binding $(\mathrm{G})$ protein $(\mathrm{P})$ receptors. As a Gi-coupled (C) member of the 7TMD/ GPCR, H5HT1aR has been studied for its relationship to other members of the receptor family [3]. Historically, $5 \mathrm{HT} 1 \mathrm{aR}$ has been associated with multiple signal transduction processes, a recent example being its linkage with c-Jun N-terminal kinase and apoptosis in fibroblasts [9]. Of particular interest are the mechanisms that 7TMD/ GPCRs use to communicate with their G proteins, effectively transducing extracellular signals to the internal cellular environment [10-13]. H5HT1aR has been studied in these contexts, both with respect to ligand site binding initiating the process $[4,5,14]$, and at the receptor $\mathrm{G}$ protein-coupling/activation step [15-18]. Fluorescence recovery/photo-bleaching technology has demonstrated that the receptor has $G$ protein-dependent cell surface dynamics [19]. Rat brain $5 \mathrm{HT} 1 \mathrm{aR}$ has constitutive activity, providing a possible mechanism for inverse agonism, a property of potential therapeutic drug relevance [20].

As the science of thermodynamics approaches its 175th anniversary, the significance of energetic processes is recognized in all systems [21]. Advances have occurred in relating macroscopic principles to microscopic entities such as biochemical receptors and their energetic transducers. General theoretical approaches to the thermodynamics of ligand-binding site interactions have been developed [22]. Further, the role that entropic factors play in protein structure [23], in lipid/water interfacial events [24], and in recognition processes by proteins serving as binding targets have started to appear [25]. In an applied context, thermodynamic analysis of protein perturbation by ligands is available as part of the process of developing new drugs [26].

The rat $5 \mathrm{HT} 1 \mathrm{aR}$ has been studied with respect to the thermodynamics of binding site ligands [27, 28]. Further, two preliminary reports have appeared, introducing thermodynamics of the H5HT1aR [29, 30]. In the present study, compounds are investigated that are relevant to both the ligand-binding site of $\mathrm{H} 5 \mathrm{HT} 1 \mathrm{aR}\left(\left[{ }^{3} \mathrm{H}\right] 8-\mathrm{OH}-\right.$ DPAT; dipropyltryptamine (DPT)) and the receptor-G protein interface (intracellular loop peptides $\mathrm{P} 8, \mathrm{P} 9$, and P11; P22-P24).

5HT1a Receptor Peptide

Thermodynamics
These peptides are members of a panel of peptides we have analyzed using agonist inhibition techniques similar to those used in this study [16-18]. Peptides P8, P9, and P11 have shown properties consistent with sites of action other than the ligand-binding site of the receptor. We have suggested that the noncompetitive nature of $\mathrm{P} 8$ and P9 could be due to interactions at sites between the receptor and G protein; the uncompetitive nature of P11 suggests possible internal sites to the three-dimensional structure of the receptor; the resulting conformational changes are then translated to the interfacial relationship between the receptor and $G$ protein.

Concentration-dependent binding of the highly specific H5HT1aR agonist $\left[{ }^{3} \mathrm{H}\right] 8-\mathrm{OH}-\mathrm{DPAT}$ is determined at the following temperatures: $0,15,25,30$, and $35^{\circ} \mathrm{C}$. From this information, the fundamental thermodynamic parameters, free energy and enthalpy can be determined for the agonist, and entropy can be computed. Then the experiments are repeated in the presence of the investigational compounds to determine the influence of these compounds on the thermodynamics of $\left[{ }^{3} \mathrm{H}\right] 8-\mathrm{OH}-\mathrm{DPAT}$ binding. The calculated thermodynamic parameters are proposed to contribute to the emerging body of understanding regarding binding and signal transduction at H5HTlaR and its relatives in the 7TMD/GPCR family. With recent publication of a crystal structure for H5HT1aR's close relative, the $\beta_{2}$-adrenergic receptor (BAR2), opportunities for modeling this family of receptors are rapidly increasing [31-33].

\section{Materials and Methods}

\section{Cell Culture}

Chinese hamster ovary $(\mathrm{CHO})$ cells transfected with the H5HTlaR gene (kind gift of Dr. John Raymond, Medical University of South Carolina, Charleston, S.C., USA) were cultured in monolayer [14]. The nutrient medium was Ham's F-12 fortified with $10 \%$ fetal calf serum (FCS) and containing $200 \mu \mathrm{g} / \mathrm{ml}$ geneticin (G418 sulfate). Standard culture conditions were $37^{\circ} \mathrm{C}$ in a humidified atmosphere of $5 \% \mathrm{CO}_{2}$. Typical time in culture was about 1 week following subculture. The line has tested negatively in our hands for mycoplasma using a PCR kit (ATCC).

\section{Receptor Preparation}

All receptors used in these experiments were components of crude transfected $\mathrm{CHO}$ membranes prepared as follows: confluent cells grown in 80 - or $175-\mathrm{cm}^{2}$ flasks were harvested in phosphate-buffered saline containing $0.25 \%$ trypsin; detached cells were diluted in ice-cold medium and sedimented by low-speed centrifugation at $4{ }^{\circ} \mathrm{C}$. The pellet was resuspended in ice-cold Earle's balanced salt solution, followed by a second low-speed, refrigerated sedimentation. The pellet was then homogenized with 


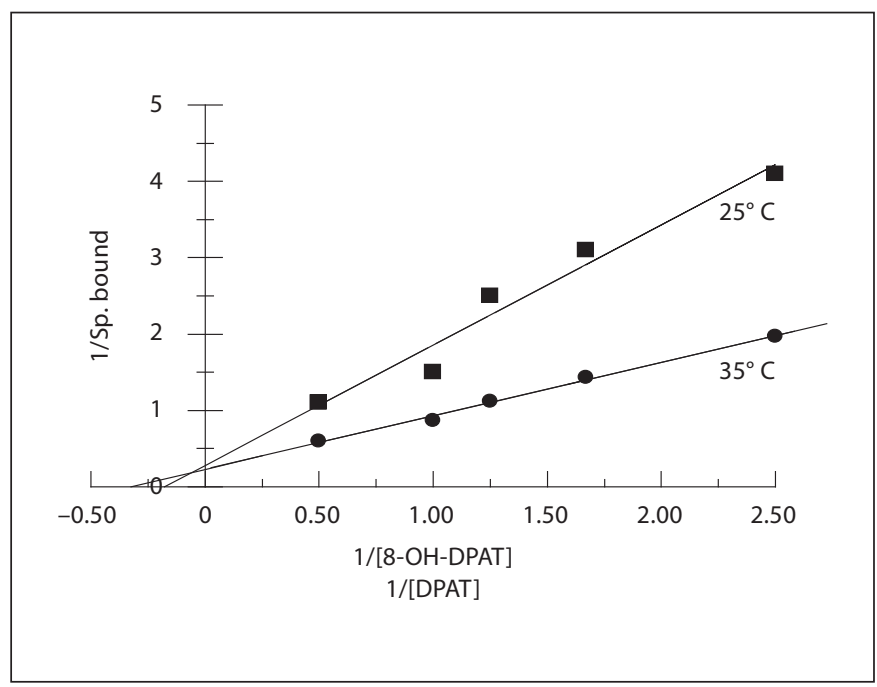

Fig. 1. Displacement of specifically bound $\left[{ }^{3} \mathrm{H}\right] 8-\mathrm{OH}-\mathrm{DPAT}$ by $\mathrm{P} 11$ at two different temperatures, 25 and $35^{\circ} \mathrm{C}$. The two separate experiments outlined were conducted in the presence of $8 \mu \mathrm{mol} / 1$ P11, one experiment at 25 and the other at $35^{\circ} \mathrm{C}$. Following binding analysis, specific binding values were transformed according to the Lineweaver-Burk linearization procedure to produce the data shown. Correlations were as follows: $25^{\circ} \mathrm{C}(\mathrm{r}=0.98) ; 35^{\circ} \mathrm{C}$ $(\mathrm{r}=1.00)$. Values on the $\mathrm{x}$ axis when inverted are (left to right): 2 , $1,0.8,0.6$, and $0.4 \mathrm{nmol} / 1$ agonist. Inverted y axis values (concentration of the agonist-receptor complex) have been multiplied by a proportionality factor for presentation purposes. Additional conditions for receptor preparation, P11 synthesis, and the binding assay can be found in the Material and Methods section.

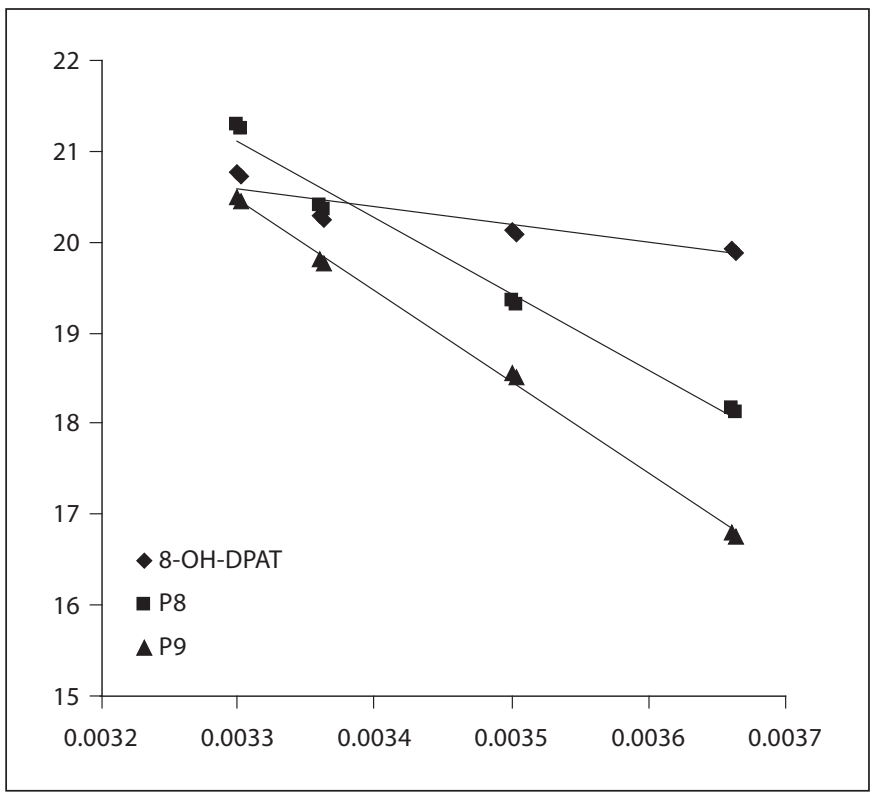

Fig. 2. van't Hoff plots for $\left[{ }^{3} \mathrm{H}\right] 8-\mathrm{OH}-\mathrm{DPAT}, \mathrm{P} 8$, and $\mathrm{P} 9$ at H5HTlaR. Binding constants (Kd) were determined for agonist alone or agonist in the presence of P8 $(10 \mu \mathrm{mol} / \mathrm{l})$ or P9 (10 $\mu \mathrm{mol} / \mathrm{l})$, using the analyses outlined in figure 1 . Inverse absolute temperatures on the $\mathrm{x}$ axis correspond to the following temperatures: $0.00325\left(35^{\circ} \mathrm{C}\right) ; 0.00330\left(30^{\circ} \mathrm{C}\right) ; 0.00336\left(25^{\circ} \mathrm{C}\right) ; 0.00347$ $\left(15^{\circ} \mathrm{C}\right) ; 0.00366\left(0^{\circ} \mathrm{C}\right)$. The y axis is the natural logarithm $(\ln )$ of the $\mathrm{Ka}(1 / \mathrm{Kd})$. Correlation coefficients were as follows: agonist $(\mathrm{r}=0.89)$; P8 $(\mathrm{r}=0.99)$; P9 $(\mathrm{r}=1.00)$. Additional experimental conditions can be found in the Material and Methods section. a Teflon pestle in a glass tube in $10 \mathrm{ml}$ of ice-cold binding buffer (50 mmol/l Tris, $4 \mathrm{mmol} / 1 \mathrm{CaCl}_{2}, 10 \mu \mathrm{mol} / \mathrm{l}$ pargyline, $\mathrm{pH} 7.4$ ) and centrifuged at $4^{\circ} \mathrm{C}$ for $450,000 \mathrm{gmin}$. The final pellet was resuspended in $30 \mathrm{ml}$ binding buffer, homogenized again in the Teflon/glass device and then for $5 \mathrm{~s}$ with a Brinkman Polytron (speed 4) in a plastic beaker. Homogenates were stored on ice, and assays were completed no more than $1.5 \mathrm{~h}$ later.

\section{Drug-Receptor Binding Assays}

Homogenate protein concentration was determined between assays by Bradford's colorimetric method [34] and subsequent receptor preparations were adjusted to achieve nominal values of $50 \mu \mathrm{g} /$ filter over the series of experiments. Binding of the agonist $\left[{ }^{3} \mathrm{H}\right] 8$-OH-DPAT $\left(\left[{ }^{3} \mathrm{H}\right] 8\right.$-hydroxy-2-(di-n-propylamino) tetralin) to receptors was determined using modifications of established protocols $[4,5,16,35,36]$. Assays run in triplicate were incubated in a shaker bath (except for $0^{\circ} \mathrm{C}$; ice; $1 \mathrm{~h}$ ) for the following temperature/time combinations: $35^{\circ} \mathrm{C} / 15 \mathrm{~min} ; 30^{\circ} \mathrm{C} / 30$ $\min ; 25^{\circ} \mathrm{C} / 30 \mathrm{~min}$, and $15^{\circ} \mathrm{C} / 45 \mathrm{~min}$. Prior experiments had shown the need to adjust the incubation times to achieve equilibrium at the various temperatures (data not shown). The incubation times used in this study are consistent with previous times used in studies of 5HT1aR thermodynamics [27, 28]. Each reaction mixture consisted of $700 \mu$ l receptor preparation, 100 $\mu \mathrm{l}$ of either binding buffer (total binding) or $10 \mu \mathrm{mol} / 15 \mathrm{HT}$ in binding buffer (nonspecific binding), $100 \mu \mathrm{l}$ of either $0.2,0.4$, $0.6,0.8,1.0$, or $2.0 \mathrm{nmol} / 1\left[{ }^{3} \mathrm{H}\right] 8-\mathrm{OH}-\mathrm{DPAT}$, and $100 \mu \mathrm{l}$ of experimental displacing agent (or $100 \mu$ l of binding buffer for nondisplacement reactions), giving a total volume of $1 \mathrm{ml}$. Incubations were terminated with $4 \mathrm{ml}$ ice-cold Tris buffer $(50 \mathrm{mmol} / \mathrm{l}$, $\mathrm{pH}$ 7.4) and rapid filtration over Whatman GF/B glass fiber filters. Two successive ice-cold 5-ml Tris buffer rinses followed. Dried filters were counted in $5 \mathrm{ml}$ of Ecoscint liquid scintillation fluid (National Diagnostics, Atlanta, Ga., USA) in a Beckman LS 6500 system.

\section{Thermodynamic Calculations}

Binding analysis was performed for $\left[{ }^{3} \mathrm{H}\right] 8-\mathrm{OH}-\mathrm{DPAT}$ at the H5HT1aR (fig. 1). The following concentrations were used: 0.2 , $0.4,0.6,0.8,1.0$ and $2.0 \mathrm{nmol} / \mathrm{l}$, through the binding constant $(\mathrm{Kd})$ of about $0.6 \mathrm{nmol} / 1$ [40]. Total and nonspecific binding was determined in triplicate in at least two independent experiments. Complete experiments were performed at the following temperatures: $0,15,25,30$, and $35^{\circ} \mathrm{C}$. The same sequences of experiments were then conducted in the presence of the following substances: P8 (10 $\mu \mathrm{mol} / \mathrm{l}) ;$ P9 (10 $\mu \mathrm{mol} / \mathrm{l}) ;$ P11 (8 $\mu \mathrm{mol} / \mathrm{l}), \mathrm{P} 22-\mathrm{P} 24(30 \mu \mathrm{mol} / \mathrm{l})$ and 
Table 1. Primary structures of the synthetic peptides and non-peptides

\begin{tabular}{ll}
\hline Peptide/agonist & Structure \\
\hline
\end{tabular}

5HT1aR agonists $\quad\left[{ }^{3} \mathrm{H}\right] 8-\mathrm{OH}-\mathrm{DPAT}$

Dipropyltryptamine

\begin{tabular}{clc}
\hline $\begin{array}{c}\text { 5HT1aR intracellular } \\
\text { loop 3 peptides }\end{array}$ & P8 & YGRIFRAARFRIRKTVKK \\
\hline 5HT1aR intracellular & P11 & RFRIRKTVKK \\
loop 2 peptides & P22 & IALDRYWAITD \\
& P23 & RYWAITDPID \\
& P24 & WAITDPIDYV \\
& & ITDPIDYVNK
\end{tabular}

P8 and P9 are from the N-terminal region of intracellular loop 3 of H5HT1aR. P11 and $\mathrm{P} 22-\mathrm{P} 24$ are from the $\mathrm{N}$-terminal region of intracellular loop 2. In each case, the Nterminal is to the left, the C-terminal to the right. Primary structures for the H5HT1aR are from Kobilka et al. [39]. Non-thermodynamic data for peptides P8, P9, and P11 [17, 18], and for DPT [5] have been previously reported. Peptides were synthesized by solid phase methods [16].
DPT (40 nmol/l). Using reciprocal analysis (with a LineweaverBurk type double inversion; fig. 1), binding constants were calculated for $\left[{ }^{3} \mathrm{H}\right] 8-\mathrm{OH}-\mathrm{DPAT}$ in every case [37]. Graphing the inverse binding constant versus reciprocal absolute temperature produces a van't Hoff plot [38] (fig. 2). The slope of this relationship is then used to calculate the standard enthalpy $(\mathrm{H})$. The standard Gibb's Free Energy (G) was determined from each binding constant at $25^{\circ} \mathrm{C}$ using an Arrhenius-like calculation: $\Delta \mathrm{G}=-\mathrm{RT} \ln$ $(1 / \mathrm{Kd})$. Having the standard enthalpy and standard free energy enabled determination of the standard entropy (S) from the Gibb's Free Energy equation $(\Delta \mathrm{G}=\Delta \mathrm{H}-\mathrm{T} \Delta \mathrm{S})$.

Synthesis and Dilution of Compounds

DPT was kindly synthesized by Dr. Charles Thompson [5] (Department of Biomedical and Pharmaceutical Sciences, University of Montana, Missoula, Mont., USA). Peptides were synthesized at the University of Montana's Murdock Molecular Biology facility as previously described [16], or purchased from New England Peptide LLC. These peptides are segments of intracellular loops of the cloned H5HT1aR $[35,39]$. Peptides stored at $-20^{\circ} \mathrm{C}$ were initially dissolved in de-ionized water or $5 \%$ DMSO. Subsequent dilutions of peptides were in binding buffer. Control experiments gave no effect of DMSO in the assay system (data not shown) at the highest final concentration used (0.5\%). These peptides are marginally soluble. We took special care to observe any changes in solubility at the lower temperatures and longer incubation times needed for some experiments. We do not believe the peptides became insoluble in any of the experiments (table 1 shows the structures of the various compounds).

\section{Data Analysis}

Binding data were averaged, and variability was assessed using the standard error of the mean (SEM). Differences between means were evaluated with the Student $t$ test (significance set at $\mathrm{p}<0.05$ ).
The binding constants for $\left[{ }^{3} \mathrm{H}\right] 8-\mathrm{OH}-\mathrm{DPAT}$ were determined from linear best-fit regression analysis of inversion plots. As with the parametric statistics, Pearson rank order correlation coefficients (r) were calculated using either PSI Plot (version 7) Software (Poly Software International) or manually with a Hewlett Packard Graphing Calculator, HP48. Correlations for specific examples are found in the figure legends. Across the study, correlation coefficients were generally in the range of $0.90-1.00$, and all are available upon request.

\section{Results}

\section{Binding Parameters}

All reported parameters are for specific binding; thus, total and nonspecific binding were determined in every case. Parallel experiments were conducted at $0,15,25,30$ and $35^{\circ} \mathrm{C}$ with the values at $30^{\circ} \mathrm{C}$ for the agonist alone integrated with a previously reported value $[29,40]$. Fixed concentrations of displacers (P8, P9, P11, P22-P24, and DPT) were chosen from previously reported experiments $[5,18,30]$ conducted at a fixed concentration of agonist $\left(0.5 \mathrm{nmol} / \mathrm{l}\right.$; near the binding constant at $\left.30^{\circ} \mathrm{C}\right)$. Demonstration of changing binding constant for agonist as a function of temperature is shown in figure 1. Here, agonist binding is measured at two temperatures, 25 and $35^{\circ} \mathrm{C}$, in the presence of $8 \mu \mathrm{mol} / \mathrm{l}$ peptide $\mathrm{P} 11$ in both cases. This double reciprocal plot resembles a Lineweaver-Burk plot from enzyme kinetics $[5,18,37]$. This proce- 
Table 2. Apparent binding constants (nmol/l) for $\left[{ }^{3} \mathrm{H}\right] 8-\mathrm{OH}-\mathrm{DPAT}$ at $\mathrm{H} 5 \mathrm{HT} 1 \mathrm{aR}$ as a function of temperature in the presence of various compounds (means \pm SEM)

\begin{tabular}{lccccc}
\hline \multirow{2}{*}{ Compound } & \multicolumn{3}{l}{ Binding constants, nmol/l, at } \\
& $0^{\circ} \mathrm{C}(273 \mathrm{~K})$ & $15^{\circ} \mathrm{C}(288 \mathrm{~K})$ & $25^{\circ} \mathrm{C}(298 \mathrm{~K})$ & $30^{\circ} \mathrm{C}(303 \mathrm{~K})$ & $35^{\circ} \mathrm{C}(308 \mathrm{~K})$ \\
\hline$\left[{ }^{3} \mathrm{H}\right] 8-\mathrm{OH}-\mathrm{DPAT}($ alone $)$ & $2.22 \pm 0.29$ & $1.80 \pm 0.10$ & $1.52 \pm 0.23$ & $0.96 \pm 0.10$ & $1.86 \pm 0.12$ \\
$\mathrm{DPT}(0.04 \mu \mathrm{mol} / \mathrm{l})$ & $\mathrm{ND}$ & $\mathrm{ND}$ & $15.23 \pm 1.02$ & $5.07 \pm 0.53$ & $3.76 \pm 0.76$ \\
$\mathrm{P} 8(10 \mu \mathrm{mol} / \mathrm{l})$ & $12.98 \pm 0.92$ & $3.95 \pm 0.23$ & $1.38 \pm 0.54$ & $0.56 \pm 0.05$ & $0.77 \pm 0.17$ \\
P9 $(10 \mu \mathrm{mol} / \mathrm{l})$ & $50.56 \pm 6.47$ & $8.79 \pm 1.12$ & $2.52 \pm 0.20$ & $1.25 \pm 0.09$ & $\mathrm{ND}$ \\
P11 $(8 \mu \mathrm{mol} / \mathrm{l})$ & $99.80 \pm 16.57$ & $7.79 \pm 0.27$ & $5.60 \pm 0.60$ & $3.76 \pm 0.37$ & $2.78 \pm 0.32$ \\
P22 & $60.8 \pm 5.2$ & $29.53 \pm 2.5$ & $5.21 \pm 0.36$ & $2.50 \pm 0.14$ & $\mathrm{ND}$ \\
P23 & $15.42 \pm 1.02$ & $4.52 \pm 0.61$ & $2.01 \pm 0.53$ & $1.85 \pm 0.24$ & $\mathrm{ND}$ \\
P24 & $68.6 \pm 23.4$ & $5.83 \pm 0.88$ & $3.78 \pm 0.37$ & $2.52 \pm 0.38$ & $\mathrm{ND}$ \\
\hline
\end{tabular}

Binding constants (nmol/l) were calculated for a minimum of 2 independent experiments of specific agonist binding (fig. 1) in triplicate as described in Materials and Methods. ND = Not determined.

Table 3. Thermodynamic parameters for $\left[{ }^{3} \mathrm{H}\right] 8-\mathrm{OH}-\mathrm{DPAT}$ binding to $\mathrm{H} 5 \mathrm{HT} 1 \mathrm{aR}$ alone and in the presence of various compounds

\begin{tabular}{llcl}
\hline Compound & $\begin{array}{l}\Delta \mathrm{G}^{\circ} \\
\mathrm{kJ} / \mathrm{mol}\end{array}$ & $\begin{array}{l}\Delta \mathrm{H}^{\circ} \\
\mathrm{kJ} / \mathrm{mol}\end{array}$ & $\begin{array}{l}\Delta \mathrm{S}^{\circ} \\
\mathrm{J} / \mathrm{mol}\end{array}$ \\
\hline$\left[{ }^{3} \mathrm{H}\right] 8-\mathrm{OH}-\mathrm{DPAT}$ (alone) & $-50(8)$ & $17(2)$ & $225(27)$ \\
DPT & $-45(3)$ & $107(20)$ & $510(63)$ \\
P8 & $-51(20)$ & $63(4)$ & $381(88)$ \\
P9 & $-49(6)$ & $84(19)$ & $446(82)$ \\
P11 & $-47(5)$ & $67(8)$ & $384(43)$ \\
P22 & $-47(3)$ & $124(13)$ & $547(49)$ \\
P23 & $-49(13)$ & $64(6)$ & $380(68)$ \\
P24 & $-48(5)$ & $86(13)$ & $452(57)$ \\
\hline
\end{tabular}

Thermodynamic parameters were determined in a minimum of 2 independent experiments as described in Materials and Methods. Standard free energies $(G)$ were calculated from agonist $\left(\left[{ }^{3} \mathrm{H}\right] 8-\mathrm{OH}-\mathrm{DPAT}\right)$ binding constants at $(298 \mathrm{~K}) 25^{\circ} \mathrm{C}$ (table 2; fig. 1). Enthalpies (H) were determined from slopes of van't Hoff plots (fig. 2). Entropies (S) were then computed from the Gibb's Free Energy Equation using the previously determined free energies and enthalpies. Values in parentheses are SEM.

dure gives identical binding constant information as derived from Scatchard analysis, and both analyses were used to evaluate the data. The binding constants for agonist, $\left[{ }^{3} \mathrm{H}\right] 8-\mathrm{OH}-\mathrm{DPAT}$, under all conditions (temperature; absence or presence of experimental ligands) are shown in table 2.

\section{Thermodynamic Parameters}

When the binding constants (inverse; i.e. Ka), determined for either agonist alone or agonist in the presence of displacers P8, 9, 11, 22-24 and DPT, are plotted as a function of absolute temperature (reciprocal), a van't Hoff plot is produced. The slope of this line is the standard enthalpy divided by the gas constant. An example for agonist alone and agonist in the presence of either P8 or $\mathrm{P} 9$ is shown in figure 2 . The binding constant at $25^{\circ} \mathrm{C}$ for agonist either alone or in the presence of displacers was used to calculate standard free energies. Thus, by generating enthalpies from van't Hoff analysis and free energies from the Arrhenius-like equation, standard entropies were calculated from the Gibb's Free Energy relationship. Table 3 summarizes the calculated thermodynamic parameters for substances analyzed in this report.

All compounds tested, yielded free energies for $\left[{ }^{3} \mathrm{H}\right] 8$ $\mathrm{OH}-\mathrm{DPAT}$ binding in the range of negative $45-51 \mathrm{~kJ} /$ mol. However, the enthalpic and entropic contributions to free energy varied widely from compound to compound. While all compounds also produced unfavorable positive enthalpies, the values varied from a low of $17 \mathrm{~kJ} /$ mol for the agonist $\left[{ }^{3} \mathrm{H}\right] 8-\mathrm{OH}-\mathrm{DPAT}$ alone, to a high of $124 \mathrm{~kJ} / \mathrm{mol}$ in the presence of P22. The peptide enthalpies varied from lows of $63 \mathrm{~kJ} / \mathrm{mol}$ in the presence of $\mathrm{P} 8$ and $64 \mathrm{~kJ} / \mathrm{mol}$ for P23, to a high of $124 \mathrm{~kJ} / \mathrm{mol}$ for P22, with P9 and P24 in the intermediate values of 84 and $86 \mathrm{~kJ} /$ mol, respectively. Neither enthalpies nor entropies (table 3) for agonist in the presence of the various peptides 
are statistically significant from each other. However, all entropies and enthalpies for agonist alone versus agonist in the presence of peptides or DPT are significantly different from each other (as determined by the Student $t$ test).

The agonist in the presence of P22 had the most favorable entropy with a value of $547 \mathrm{~J} / \mathrm{mol}$, more than double the value for agonist alone at $225 \mathrm{~J} / \mathrm{mol}$. The next most favorable was the bulky partial agonist DPT at 510 $\mathrm{J} / \mathrm{mol}$. Entropies for agonist in the presence of the peptides varied from the least favorable 380, 381, and 384 $\mathrm{J} / \mathrm{mol}$ for P23, P8, and P11, respectively, to $547 \mathrm{~J} / \mathrm{mol}$ for P22.

\section{Discussion}

Possible implications of these results may be considered in the context of previous thermodynamic understanding of the $5 \mathrm{HT} 1 \mathrm{aR}$, and the current findings can be analyzed in the perspective of known results with related 7TM/GPCR. Binding thermodynamics of $\left[{ }^{3} \mathrm{H}\right] 8-\mathrm{OH}-$ DPAT in $\mathrm{H} 5 \mathrm{HT} 1 \mathrm{aR}$ reported in this study and rat $5 \mathrm{HT} 1 \mathrm{aR}$ $[27,28]$ suggest some differences. When the agonist is directly bound to receptor, Dalpiaz et al. [28] determined a negatively sloping van't Hoff relationship for rat $5 \mathrm{HTlaR}$ similar to that for H5HT1aR (fig. 2). The standard free energies are similar: $-51.3 \mathrm{~kJ} / \mathrm{mol}$ for rat $5 \mathrm{HTlaR}$ and -50 $\mathrm{kJ} / \mathrm{mol}$ for H5HT1aR (table 3). The enthalpic and entropic components of these free energies are quite different though. The standard enthalpy is less unfavorable in $\mathrm{H} 5 \mathrm{HTlaR}(17 \mathrm{~kJ} / \mathrm{mol})$ versus $(58 \mathrm{~kJ} / \mathrm{mol})$ in rat $5 \mathrm{HTlaR}$; compensating for this difference is the more favorable entropic value in rat $5 \mathrm{HTlaR}(366 \mathrm{~kJ} / \mathrm{mol})$ compared to 225 $\mathrm{kJ} / \mathrm{mol}$ in H5HT1aR (table 3). Therefore, H5HT1aR binding to agonist appears to be balanced between entropic and enthalpic considerations. Or, in other words, agonist binding to H5HT1aR is less entropically driven than it is in rat $5 \mathrm{HT} 1 \mathrm{aR}$.

In the less direct comparison where $\left[{ }^{3} \mathrm{H}\right] 8-\mathrm{OH}-\mathrm{DPAT}$ was displaced from rat $5 \mathrm{HT} 1 \mathrm{aR}$ by serotonin [27], a smaller standard free energy was found $(-47.6 \mathrm{~kJ} / \mathrm{mol}$; the enthalpic value was favorably negative $(-14 \mathrm{~kJ} / \mathrm{mol})$, and the entropy was less favorable $(113 \mathrm{~kJ} / \mathrm{mol})$. Thus, H5HTlaR lies on a continuum between the direct (highly entropy driven) and indirect (slightly positive van't Hoff slope; driven by both entropy and enthalpy) determinations at rat 5HTlaR. It is unclear how the difference in design of these direct and indirect comparisons may temper these conclusions.

5HT1a Receptor Peptide

Thermodynamics
Expanding this comparison between rat 5HTlaR and $\mathrm{H} 5 \mathrm{HTlaR}$ in the current study, the other ligand-binding site-directed agent, partial agonist [5], DPT, provides contrast with the smaller, more compact agonist, $\left[{ }^{3} \mathrm{H}\right] 8$ OH-DPAT. When DPT is present, values for $\left[{ }^{3} \mathrm{H}\right] 8-\mathrm{OH}-$ DPAT thermodynamics in table 3 indicate a smaller negative standard free energy $(-45 \mathrm{~kJ} / \mathrm{mol})$, and a much larger standard enthalpy of 107 (vs. 17) $\mathrm{kJ} / \mathrm{mol}$ in conjunction with a much larger standard entropy of 510 (vs. 225) kJ/ $\mathrm{mol}$ ). These values are probably fitting for a molecule that binds with lower affinity (100 vs. $0.6 \mathrm{nmol} / \mathrm{l})$ in a highly entropic process for a bulky molecule.

At H5HT1aR, these distinctions between $\left[{ }^{3} \mathrm{H}\right] 8-\mathrm{OH}-$ DPAT alone and in the presence of DPT may not only explain the affinity differences but also the efficacy transition from a full to partial agonist. This difference between full agonist (8-OH-DPAT) and partial agonist (DPT) may fit the observations made by Dalpiaz et al. [28] for antagonists such as NAN-190, propranolol, pindolol, and alprenolol at rat $5 \mathrm{HT} 1 \mathrm{aR}$. While DPT is a substantial agonist [5], it clearly does not have full agonistic properties. Thus, the comparative thermodynamics of $8-\mathrm{OH}$ DPAT alone and in the presence of DPT observed in the current study may track this transition in intrinsic activity.

There is significant differentiation in the current study regarding the thermodynamics of agonist alone or agonist in the presence of any of the other agents. Any of the experimental agents, active-site directed or not, perturb the receptor- $G$ protein complex such that the enthalpic environment for agonist binding becomes less favorable while the entropic environment for agonist binding becomes more favorable. The individual values for the peptide influences on agonist binding do not significantly differ from each other.

The six H5HT1aR intracellular loop peptides examined in this study are postulated to bind, not at the ligand site, but either at the receptor-G protein interface or at internal receptor-receptor sites [16-18]. The contrasting thermodynamics of these agents relative to each other and relative to the ligand-binding site-directed agents, may contribute insight to their unusual modes and sites of interaction.

P8 and P9 have similar standard free energies of -51 and $-49 \mathrm{~kJ} / \mathrm{mol}$, respectively. They arrive at these points by somewhat divergent means. P8, the larger of the two ic3 peptides, has a less unfavorable standard enthalpy than P9 (63 vs. $84 \mathrm{~kJ} / \mathrm{mol}$; table 3 ) and less favorable standard entropy ( $381 \mathrm{vs.} 446 \mathrm{~kJ} / \mathrm{mol}$ ). These separations may mostly be due to P9's smaller size (10 amino acids rather 
than 18). Despite their similar binding characteristics as determined by $\mathrm{Ki}$ in agonist inhibition (0.56 vs. 1.25 $\mathrm{nmol} / \mathrm{l}$ at $30^{\circ} \mathrm{C}$ ), and apparent noncompetitive mechanisms [18], the two peptides are unique when effector properties are studied. P8 acts like the other active loop 3 peptides studied in being able to directly activate $\mathrm{Gi}$ as demonstrated by GTP incorporation assays and cAMP determinations.

$\mathrm{P} 9$, on the other hand, has the completely unusual property of decreasing GTP incorporation, as if it has regulatory properties at the GTP-binding site of the G protein. Whether the trends in different thermodynamic values derived for P9 go beyond the size difference with P8, to partially explain this signal transduction difference, awaits greater knowledge of the intimate 3D interactions between H5HTlaR and Gi.

P11 is similar in size to P9 at 11 amino acids but is derived from the TM3/intracellular loop 2 transition region. Its standard free energy at $-47 \mathrm{~kJ} / \mathrm{mol}$ is not quite as favorable as either P8 or P9 from loop 3. This free energy is the result of an intermediate enthalpy at $67 \mathrm{~kJ} / \mathrm{mol}$, nearer the value of $\mathrm{P} 8$ than $\mathrm{P} 9$, and a standard entropy of $384 \mathrm{~kJ} / \mathrm{mol}$, almost the same as that of P8. Again, these numbers may simply reflect that P11 is intermediate in size between P9 and P8, although much closer to P9. There is a surprising mechanistic difference between P11 on the one hand and P8 and P9 on the other in that P11 shows uncompetitive characteristics [18].

Peptides P22-P24 are farther toward mid-loop and the TM4 transition with intracellular loop 2 compared to P11 (table 1). It has been postulated that the TM4 side of intracellular loop 2 in $\mathrm{H} 5 \mathrm{HT} 1 \mathrm{aR}$ is positioned to couple to and participate in $G$ protein activation following conformational changes produced by the initial coupling of the TM3 side to either other receptor components or the G protein itself $[15,18]$. Peak Gi activation occurs at P23, dropping off on either side with P22 and P24. This symmetrical difference is also seen with both the enthalpic and entropic parameters reported in table 3, possibly linking these functional and energetic differences in receptor dynamics.

To our knowledge, there are no other reports on the thermodynamic properties of 5HT1aR loop peptides. Nevertheless, it is interesting to note that the ligand binding-site agonist vs. antagonist entropic differences described previously $[27,28]$ for rat $5 \mathrm{HTlaR}$ and discussed earlier in this communication relative to 8-OH-DPAT and DPT at H5HTlaR may still apply to the limited peptide sample reported in the current study. That is, the transition from 'agonist' (a peptide capable of activating
G protein on its own) vs. 'antagonist' (a peptide incapable of $G$ protein activation) seems to suggest that whether the receptor is being perturbed at the ligand-binding site or whether the $G$ protein is being directly influenced by peptide in a way that mimics agonist-activated receptor, the outcome is energetically similar.

Comparison of these thermodynamic differences in light of the newly available BAR crystal structure [31-33] and the eventual crystal structures for 5HTlaR and other GPCRs should give considerable insight into the structural and functional characteristics of this class of receptors. For example, the entropic changes observed in these studies with H5HT1aR may be related to the surprisingly 'open' crystal structure of BAR that enables the TM segments and attached intracellular loops of BAR to interact with the water cluster. This situation may well fit into the broad parameters of water/lipid dynamics at interfaces in biological systems [24].

A few points seem to stand out in the context of general thermodynamic theory for receptor interactions. First, the paradigm used to analyze receptor thermodynamics is crucial to the conclusions reached. Second, the binding sites for different receptors systems are quite different energetically [41-45]. These energetic differences have led to the theory of thermodynamic discrimination. That is, although there may not be general entropic versus enthalpic differences between agonists and antagonists, in a given receptor system, agonist and antagonist binding may be so discriminated. Thus, for example, at the nicotinic neuronal receptor, agonist binding is driven by both enthalpy and entropy, whereas antagonist binding is driven by entropy only [46]. Antagonist binding is not always purely entropy driven. In inotropic glutamate receptors, displacement of the agonist (S)-glutamate by antagonists is enthalpy driven [47]. Partial agonists can fit nicely into this paradigm.

In the thermodynamically discriminated adenosine A1 receptor system, the investigational drug LUF5831 was shown to be a partial agonist, as its binding to the receptor fell in between the thermodynamic parameters generated by agonist and antagonist binding [48]. Much as with these other receptor systems, the current findings can play a role in contributing to basic molecular understanding of 5HT1aRs and the application of this information to new drug development, and to the place that $5 \mathrm{HTlaR}$ has in the broader context of biological receptors. 


\section{Acknowledgements}

Our studies with H5HT1aR would have been impossible without the generous donation of cloned H5HT1aR by Dr. John Raymond. The following people were instrumental in assisting with this work: Jacquelyn Burgstrom, Leah Madden, Melissa Morin, Lynn Parker, Ben Seaver, Carley Squires, and Michelle Spotted Wolf. This work was supported by NIH grants: RR10169 and GM/ OD 54302-01 and 02, and P20 RR15583 to the UM COBRE Center for Structural and Functional Neuroscience from NCRR.

\section{References}

$\checkmark 1$ Barnes NM, Sharp T: A review of central 5 -HT receptors and their functions. Neuropharmacology 1999;38:1083-1152.

-2 Hoyer DE, Clarke JR, Fozard PR, Hartig GR, Martin GR, Mylecharane EW, Saxena PR, Humphrey PPA: International Union of Pharmacology classification of receptors for 5-hydroxytryptamine (serotonin). Pharmacol Rev 1994:46:157-203.

-3 Raymond JR, Mukhin YV, Gelasco A, Turner J, Collinsworth G, Gettys TW, Greal JS, Garnovskaya MN: Multiplicity of mechanisms of serotonin receptor signal transduction. Pharmacol Ther 2001;92:179-212.

4 Russo EB, Burnett A, Hall B, Parker KK: Agonistic properties of cannabidiol at 5-HTla receptors. Neurochem Res 2005;30:10371043.

5 Thiagaraj HV, Russo EB, Burnett A, Goldstein E, Thompson CM, Parker KK: Binding properties of dipropyltryptamine at the human 5-HTla receptor. Pharmacology 2005; 74:193-199.

-6 Rausch JL, Johnson ME, Kasik KE, Stahl SM: Temperature regulation in depression: functional 5HT1A receptor adaptation differentiates antidepressant response. Neuropsychopharmacology 2006;31:2274-2280.

7 Klisch J, Bode-Greuel KM, Horvath E, Klisch C, Els T: Additive neuroprotective effect of ketanserin and ipsapirone on the hippocampal damage after transient forebrain ischemia in the Mongolian gerbil. Neurosci Lett 2003;342:25-28.

-8 Muller CP, Carey RJ, Huston JP, De Souza Silva MA: Serotonin and psychostimulant addiction: focus on 5-HT1A-receptors. Prog Neurobiol 2007;81:133-178.

-9 Turner JH, Garnovskaya MN, Raymond JR: Serotonin 5-HT1A receptor stimulates c-Jun $\mathrm{N}$-terminal kinase and induces apoptosis in Chinese hamster ovary fibroblasts. Biochim Biophys Acta 2007;1773:391-399.

10 Hamm HE: How activated receptors couple to G proteins. Proc Natl Acad Sci USA 2001; 98:4819-4821.

11 Ja WW, Roberts RW: In vitro selection of state-specific peptide modulators of $\mathrm{G}$ protein signaling using mRNA display. Biochemistry 2004;43:9265-9275.

12 Seabra MC, Wasmeier C: Controlling the location and activation of Rab GTPases. Curr Opin Cell Biol 2004;16:451-457.
13 Tesmer VM, Kawano T, Shankaranarayanan A, Kozasa T, Tesmer JJG: Snapshot of activated $G$ proteins at the membrane: the Galphaq-GRK2-Gbetagamma complex. Science 2005;310:1686-1690.

$\checkmark 14$ Raymond JR, Mukhin YV, Gettys TW, Garnovskaya MN: The recombinant 5-HT1a receptor: $\mathrm{G}$ protein coupling and signaling pathways. Br J Pharmacol 1999;127:17511764.

15 Varrault A, Nguyen DL, Mcclue S, Harris B, Jouin P, Bockaert J: 5-Hydroxytryptaminela receptor synthetic peptides: mechanisms of adenylyl cyclase inhibition. J Biol Chem 1994;269:16720-16725.

16 Ortiz TC, Devereaux MC, Parker KK: Structural variants of a human 5-HT1a receptor intracellular loop 3 peptide. Pharmacology 2000;60:195-202.

17 Thiagaraj HV, Ortiz TC, Burnett A, Parker $\mathrm{KK}: \mathrm{G}$ protein coupling and activation characteristics of intracellular loops 2 and 3 or the 5HT1a receptor. Trends Comp Biochem Physiol 2002;9:117-129.

18 Thiagaraj HV, Ortiz TC, Devereaux MC Jr, Seaver B, Hall B, Parker KK: Regulation of G proteins by human 5 -HTla receptor TM3/i2 and TM5/i3 loop peptides. Neurochem Int 2007;50:109-118.

19 Pucadyil TJ, Chattopadhyay A: The human serotonin1A receptor exhibits G-protein-dependent cell surface dynamics. Glycoconj J 2007;24:25-31.

20 Martel JC, Ormiere AM, Leduc N, Assie MB, Cussac D, Newman-Tancredi A: Native rat hippocampal 5-HT1A receptors show constitutive activity. Mol Pharmacol 2007;71 638-643.

21 Haw M: From steam engines to life? Am Scient 2007;95:472-474.

22 Kuntz ID, Chen K, Sharp KA, Kollman PA: The maximal affinity of ligands. Proc Natl Acad Sci USA 1999;96:9997-10002.

23 Sullivan DC, Kuntz ID: Distribution in protein conformation space: implications for structure prediction and entropy. Biophys J 2004;87:113-120.

24 Chandler D: Interfaces and the driving force of hydrophobic assembly. Nature 2005;437: 640-647.

25 Frederick KK, Marlow MS, Valentine KG, Wand AJ: Conformational entropy in molecular recognition by proteins. Nature 2007; 448:325-329.

26 Weber PC, Salemme FR: Applications of calorimetric methods to drug discovery and the study of protein interactions. Curr Opin Struct Biol 2003;13:115-121.
27 Dalpiaz A, Gessi S, Borea PA, Gilli G: Binding thermodynamics of serotonin to ratbrain 5-HT1A, 5-HT2A, and 5-HT3 receptors. Life Sci 1995;57:141-146.

28 Dalpiaz, A, Borea PA, Gessi S, Gilli, G: Binding thermodynamics of 5-HT1A receptor ligands. Eur J Pharmacol 1996;312:107-114.

29 Burnett A, Goldstein E, Christians A, Hall B, Parker KK: Thermodynamic properties of the human 5HT1a receptor. Soc Neurosci Abstr 2003;29:362-318.

30 Hall B, Squires C, Parker KK: Energetics at the human 5HTla RECEPTOR Loop 2-Gi interface. Soc Neurosci Abstr 2007;33:465468.

-31 Cherezov V, Rosembaum DM, Hanson, MA, Rasmussen SGF, Thian FS, Kobilka TS, Choi HJ, Kuhn P, Weis WI, Kobilka BK, Steven RC: High-resolution crystal structure of an engineered human beta2-adrenergic $\mathrm{G}$ protein-coupled receptor. Science 2007;318: 1258-1265.

-32 Rasmussen SG, Choi HJ, Rosenbaum DM, Kobilka TS, Thian FS, Edwards PC Burghamer M, Ratnala, VRP, Sanishvili R, Fischetti RF, Schertler, GFX, Weis WI, Kobilka BK: Crystal structure of the human beta(2) adrenergic G-protein-coupled receptor. Nature 2007;450:383-387.

33 Rosenbaum DM, Cherezov V, Hanson MA, Rasmussen SGF, Thian FS, Kobilka TS, Choi HJ, Yao XJ, Weis WI, Steven, RC, Kobilka BK: GPCR engineering yields high-resolution structural insights into beta2-adrenergic receptor function. Science 2007;318: 1266-1273.

34 Bradford MM: A rapid sensitive method for the quantitation of microgram quantities of protein utilizing the principle of protein-dye binding. Anal Biochem 1976;72:248-254.

35 Fargin A, Raymond JR, Lohse MJ, Kobilka BK, Caron MG, Lefkowitz RJ: The genomic clone G-21 which resembles a beta-adrenergic receptor sequence encodes the 5-HTla receptor. Nature 1988;335:358-360.

36 Nelson DL, Monroe PJ, Lambert G, Yamamura HI: $\left[{ }^{3} \mathrm{H}\right]$ Sprioxatrine labels a serotoninla-like site in the rat hippocampus. Life Sci 1987;41:1567-1576.

37 McGonigle P, Molinoff PB: Quantitative aspects of drug-receptor interactions; in Spiegel GJ (ed): Basic Neurochemistry: Molecular, Cellular, and Medical Aspects, ed 4. New York, Raven Press, 1989, pp 183-201.

38 Hitzemann R: Thermodynamic aspects of drug-receptor interactions. Trends Pharmacol Sci 1988;9:408-411. 
39 Kobilka BK, Frielle T, Collins S, Yang-Feng T, Kobilka TS, Francke U, Lefkowitz RJ, Caron MG: An intronless gene encoding a potential member of the family of receptors coupled to guanine nucleotide regulatory proteins. Nature 1987;329:75-79.

40 Weber JT, Hayataka K, O’Connor M-F, Parker KK: Rabbit cerebral cortex 5HT1a eceptors. Comp Biochem Physiol 1997;117C:1924.

-41 Urban JD, Clarke WP, von Zastrow M, Nichols DE, Kobilka B, Weinstein H, Javitch JA, Roth BL, Christopoulos A, Sexton PM, Miller KJ, Spedding M, Mailman RB: Functional selectivity and classical concepts of quantitative pharmacology. J Pharmacol Exp Ther 2007;320:1-13.
42 Weiland GA, Minneman KP, Molinoff PB: Thermodynamics of agonist and antagonist interactions with mammalian beta-adrenergic receptors. Mol Pharmacol 1980;18:341347.

43 Zahniser NR, Molinoff PB: Thermodynamic differences between agonist and antagonist interactions with binding sites for $\left[{ }^{3} \mathrm{H}\right]$ spiroperidol in rat striatum. Mol Pharmacol 1983; 23:303-309.

44 Kilpatrick GJ, Tayar NE, de Waterbeemd H, Jenner P, Testa B, Marsden CD: The thermodynamics of agonist and antagonist binding to dopamine D-2 receptors. Mol Pharmacol 1986;30:226-234.

45 Hitzemann R, Murphy M, Curell J: Opiate receptor thermodynamics: agonist and antagonist binding. Eur J Pharmacol 1985;108: 171-177.

-46 Borea PA, Varani K, Piaz SG, Gilli P, Gilli G: Receptor binding thermodynamics at the neuronal nicotinic receptor. Curr Top Med Chem 2004;4:361-368.
47 Kasper C, Pickering DS, Mirza O, Olsen L, Kristensen AS, Greenwood JR, Liljefors T, Schousboe A, Watjen F, Gajhede M, Sigurskjold BW, Kastrup JS: The structure of a mixed gluR2 ligand-binding core dimer in complex with (S)-glutamate and the antagonist (S)-NS1209. J Mol Biol 2006;357:11841201.

48 Heitman LH, Mulder-Krieger T, Spanjersberg RF, von Frijtag JK, Kunzel D, Dalpiaz A, Ijzerman AP: Allosteric modulation, thermodynamics and binding to wild-type and mutant (T277A) adenosine A1 receptors of LUF5831, a novel nonadenosine-like agonist. Br J Pharmacol 2006; 147:533-541. 